\title{
Immunogenic outer-membrane proteins of Haemophilus influenzae type $b$ in infection
}

\author{
P. R. Langford, ${ }^{*}$ A. E. Williams $\dagger$ and E. R. Moxon \\ Molecular Infectious Diseases Group, Institute of Molecular Medicine, Oxford OX3 9DU, UK
}

(Received 18 June 1991; revised 30 September 1991; accepted 21 October 1991)

\begin{abstract}
Outer-membrane proteins (OMPs) from Haemophilus influenzae type b (strain Eagan), grown both in vitro (broth) and in vivo (rat intra-peritoneal), were separated by SDS-PAGE. The major OMPs were present in both growth conditions although the amounts of OMP a and OMP $d$ were reduced in rat-grown organisms. There were strong additional bands in in-vivo-grown organisms at 51 and $92 \mathrm{kDa}$. Antiserum was raised in rabbits against in-vivogrown bacteria, and absorbed with lysates of in-vitro-grown bacteria. This serum was used in Western blot analysis of OMPs from in-vitro- and in-vivo-grown cells to identify immunogenic proteins present in infection. These infection-associated OMPs had apparent molecular masses of $43 \mathrm{kDa}, 48 \mathrm{kDa}, 81 \mathrm{kDa}$ and $>200 \mathrm{kDa}$. Bands of reactivity, of the same molecular mass as some of these, were found on immunoblots when rat and human convalescent sera were used as the source of primary antibody. In particular, a band of $81 \mathrm{kDa}$ was recognized by pooled rat and three human convalescent sera.
\end{abstract}

\section{Introduction}

Information concerning virulence factors and protective antigens of micro-organisms expressed in vivo is crucial in understanding disease processes and the design of antimicrobial and vaccine strategies. Bacteria can alter their metabolism and composition in response to environmental change (Brown \& Williams, 1985). Examples of environmentally-controlled virulence factors include temperature regulation of fimbriae in Escherichia coli (Jacobs \& de Graaf, 1985), osmotic regulation of cholera toxin (Miller et al., 1987) and pilus production (Taylor et al., 1987) in Vibrio cholerae, and iron regulation of Corynebacterium diphtheriae toxin (Murphy et al., 1974). Many virulence factors are expressed only in environmental conditions similar to those found in the host (Moulder, 1985). In general, when studying bacterial virulence, investigators have used organisms grown in conventional broth media. Thus important antigens or virulence factors may have been overlooked.

Haemophilus influenzae type $\mathrm{b}(\mathrm{Hib})$ is one of the

- Author for correspondence. Tel. (0865) 221061; fax (0865) 220479.

† Present address: AFRC and MRC Neuropathogenesis Unit, Ogston Building, West Mains Road, Edinburgh EH9 3JF, UK.

Abbreviations: ALP, alkaline phosphatase; BHI, brain heart infusion; Hib, Haemophilus influenzae type b; i.p., intra-peritoneally. commonest causes of meningitis in young children. The organism can colonize the nasopharynx (reviewed by Moxon, 1990) pass to the blood stream (possibly by epithelial/endothelial interactions), multiply in the vascular compartment (Rubin et al., 1985) and/or macrophages (Williams et al., 1991), cross the blood/CSF barrier by unknown mechanisms and multiply in the CSF. Adaptation and survival in these contrasting environments may require the expression of different surface components. The outer-membrane proteins (OMPs) of Hib have been extensively investigated to identify possible virulence factors and vaccine candidates. One approach has been to use acute and/or convalescent sera to investigate the immunological response of patients and experimental animals to OMPs by Western blot analysis (Hansen et al., 1981; Gulig et al., 1982; Loeb \& Smith, 1982; Erwin et al., 1988). However, without exception, outer membranes isolated from broth-grown organisms were used in these studies. In this study we have isolated outer-membrane material from Hib grown either in broth or harvested directly from infected rats, and used rabbit serum raised against whole cells of in-vivo-(rat)-grown bacteria to identify immunogenic proteins 'novel' to infection. Bands were observed on immunoblots of the same molecular mass as those present in infection when convalescent sera from rats and patients were used as the source of primary antibody. 


\section{Methods}

Bacterium and in vitro growth conditions. Hib strain Eagan (Anderson et al., 1972) was grown to exponential phase $\left(\mathrm{OD}_{490}=0.27\right)$ in Brain Heart Infusion (BHI) broth supplemented with $2 \mu \mathrm{g} \mathrm{ml} \mathrm{m}^{-1}$ protoporphyrin IX and $\left.2 \mu \mathrm{g} \mathrm{m}\right|^{-1} \mathrm{NAD}$ at $37^{\circ} \mathrm{C}$ on an orbital shaker (200 r.p.m.). Overnight Fe-restricted cultures were obtained by growth in supplemented BHI broth plus $100 \mu$ m-ethylenediaminedi-(ohydroxy)phenylacetic acid (Morton \& Williams, 1990), the latter compound having been freed from contaminating $\mathrm{Fe}$ by the method of Rogers (1973). Eagan was used because of the considerable data that has accumulated on this organism, leading to the suggestion that it should be adopted as a reference type b strain for investigations of Hib pathogenicity (Kroll \& Moxon, 1989).

Growth of organisms in vivo (rat). Exponential-phase cells were harvested, washed once and resuspended in PBS at a concentration of $5 \times 10^{3}$ c.f.u. $\mathrm{ml}^{-1}$ and $0.1 \mathrm{ml}$ of this was inoculated intra-peritoneally (i.p.) into 5-day-old Sprague Dawley rat pups. Twenty-four hours later, i.p. washings [ $1 \mathrm{ml}$ per rat in MEM (Gibco)] were aseptically collected, pooled and centrifuged $\left(150 \mathrm{~g}, 5 \mathrm{~min}, 4^{\circ} \mathrm{C}\right)$ to remove peritoneal cells. The supernatant was recentrifuged $\left(5000 \mathrm{~g}, 20 \mathrm{~min}, 4^{\circ} \mathrm{C}\right)$, the pellet was resuspended in double distilled water to lyse remaining peritoneal cells and bacteria were collected by recentrifugation $(5000 \mathrm{~g}, 20 \mathrm{~min}$, $4{ }^{\circ} \mathrm{C}$ ). The pellet was resuspended in $1 \mathrm{ml} 10 \mathrm{~mm}$-HEPES (pH 7.4) and stored at $-20^{\circ} \mathrm{C}$ until required. Pooled blood obtained by cardiac puncture from 3 animals, 4 weeks post i.p. infection with Eagan, was the source of convalescent rat serum (Hansen et al., 1981). Sera were stored at $-70^{\circ} \mathrm{C}$ as $0.1 \mathrm{ml}$ samples until required.

Inoculation of rabbits. Rabbit antiserum was raised against in-vivogrown bacteria (anti-in-vivo) as follows. Freshly-harvested in-vivogrown bacteria were washed twice and resuspended in PBS to a concentration of $4 \times 10^{8}$ c.f.u. $\mathrm{ml}^{-1}$ and $0.4 \mathrm{ml}$ was inoculated into the ear vein of New Zealand White rabbits $(2 \mathrm{~kg})$ at weekly intervals. After 9 weeks, rabbits were bled from the marginal ear vein of the opposite ear and serum was stored at $-20^{\circ} \mathrm{C}$ in small aliquots until required.

Convalescent sera. Three patients with a positive diagnosis of Hib meningitis were the source of human convalescent sera. Age at diagnosis was 12 months (C), 3 months (D) and 14 months (E) and convalescent sera was collected at 3,4 and 5 weeks post diagnosis, respectively.

Isolation of outer membranes and SDS-PAGE. Outer-membrane material was obtained by extraction of crude cell envelopes with Triton $\mathrm{X}-100 / 10 \mathrm{~mm}-\mathrm{Mg}^{2+}$ (Schnaitman, 1971). Protein concentration was measured by a modification (Stoscheck, 1990) of the method of Bradford (1976) using bovine serum albumin as standard. Approximately $0.5-1.0 \mu \mathrm{g}$ of membrane protein was obtained from each rat. SDS-PAGE was performed on $12.5 \%(\mathrm{w} / \mathrm{v})$ acrylamide gels as described previously (Allan et al., 1987) and OMPs were stained with silver using the Amersham kit (RPN.17)

Antibody absorption. Rabbit anti-in-vivo serum $(1 \mathrm{ml})$ was absorbed twice with sonicates of $1 \times 10^{11} \mathrm{c}$.f.u. of in-vitro-grown organisms in $0.5 \mathrm{ml}$ PBS at $0{ }^{\circ} \mathrm{C}$ for $30 \mathrm{~min}$. Following centrifugation $(13500 \mathrm{~g}$, $10 \mathrm{~min}, 0{ }^{\circ} \mathrm{C}$ ) absorbed antiserum was stored at $-70^{\circ} \mathrm{C}$ until required. Any dilution of serum with PBS was taken into account, and a volume of absorbed serum equivalent to $0.1 \mathrm{ml}$ of original serum was used in the immunoblots.

Immunoblotting. Proteins were transferred to $0.45 \mu \mathrm{m}$ nitrocellulose sheets by the method of Towbin et al. (1979). Membranes were soaked in $10 \mathrm{mM}$-Tris/ $0.9 \% \mathrm{NaCl}(\mathrm{pH} \mathrm{7.4)} / 0.3 \%$ Tween 20 (TN20) for $1 \mathrm{~h}$ to block non-specific binding sites. The nitrocellulose strips with transblotted proteins were incubated in primary antibody, consisting of
$0.1 \mathrm{ml}$ rabbit, rat or human sera in $20 \mathrm{ml}$ TN20, for $2 \mathrm{~h}$ at room temperature, and washed extensively in TN20. This was followed by incubation ( $2 \mathrm{~h}$ at room temperature) in secondary antibody $(1 / 1000$ dilution in TN20) comprising affinity-isolated goat anti-rabbit IgG alkaline phosphatase (ALP) conjugate, goat anti-rat IgG ALP conjugate or goat anti-human IgG ALP conjugate (all from Sigma) as appropriate. After washing in buffer without Tween 20, blots were developed using the method of Blake et al. (1984). All washing and incubation procedures were performed on an orbital shaker ( 60 r.p.m.).

\section{Results}

\section{OMP profiles}

The OMP profiles of in-vitro- and in-vivo-grown organisms are shown in Fig. 1. The major OMPs were present in both growth conditions, although the amounts of OMP $a$ and OMP $d$ were reduced in rat grown organisms. There were strong additional bands in in-vivo-grown organisms at 51 and $92 \mathrm{kDa}$, and these were also prominent on Coomassie blue R-250 staining (data not shown). No detergent-insoluble material was found from i.p. washings of control animals or from inflammatory cell preparations obtained after the first centrifugation following direct harvesting (see Methods). The same result was found when sham-infected rats were used as controls (van Alphen et al., 1990).

\section{Identification of proteins present in infection and their immunogenicity to convalescent sera}

OMPs present in infection were identified using rabbit serum raised against in-vivo-grown organisms and absorbed with whole cell lysates of in-vitro-grown bacteria. Four strong bands were present in membranes isolated from broth-grown organisms (Fig. 2, lane A1). These were bands equivalent to the major OMPs d $(37 \mathrm{kDa})$, e $(31 \mathrm{kDa}), \mathrm{d}^{*}(29 \mathrm{kDa})$ and a minor protein at $79 \mathrm{kDa} . \mathrm{d}^{*}$ is the non-heat modified form of $\mathrm{d}$ (van Alphen et al., 1983). Exactly the same result was found if membrane preparations were used from Fe-restricted grown cells (data not shown). In the in vivo membrane preparation, a number of immunogenic proteins with molecular masses of $43 \mathrm{kDa}, 48 \mathrm{kDa}, 81 \mathrm{kDa}$ and $>200 \mathrm{kDa}$ were also observed suggesting that these were present in infection (Fig. 2, lane A2). Rabbit pre-immune serum recognized bands at $37 \mathrm{kDa}$ and $31 \mathrm{kDa}$ in in vivo and in vitro membranes and in addition at $56 \mathrm{kDa}$ in in vitro membranes (data not shown).

When convalescent sera were used as the source of antibodies, bands were seen that had the same molecular mass as the 'infection specific' proteins (Fig. 2, lanes B2, C2, D2 and E2). These were not present in membranes isolated from broth-grown organisms (Fig. 2, lanes B1, 


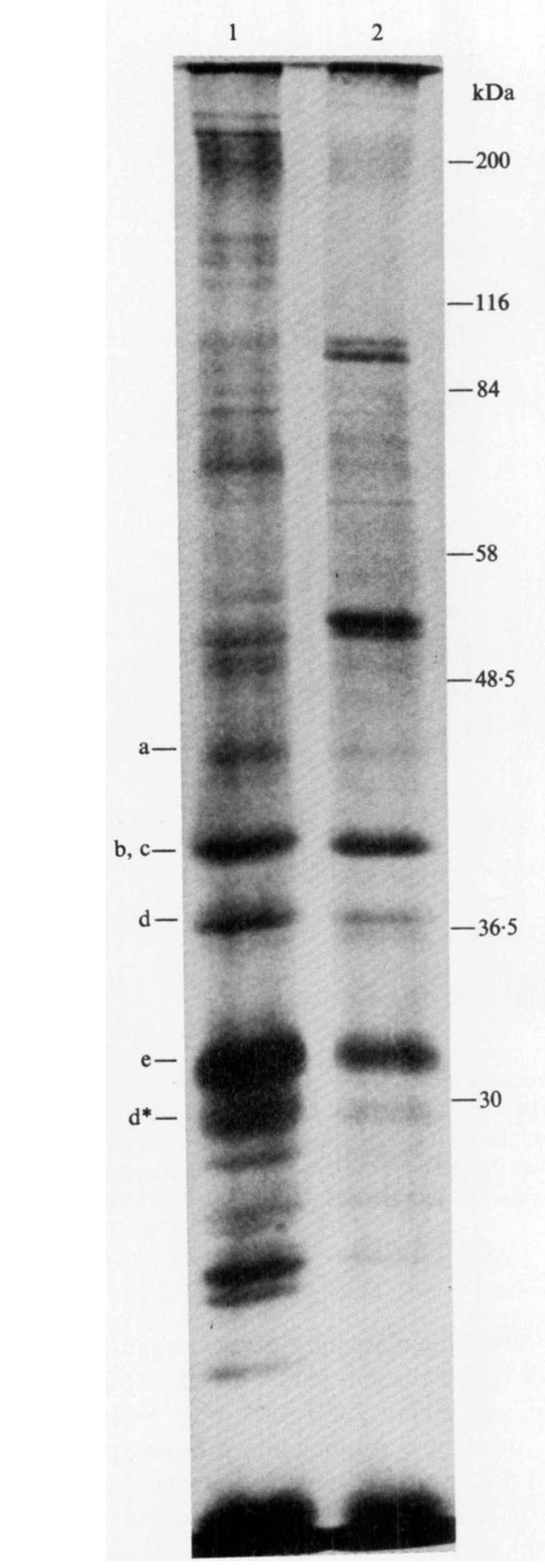

Fig. 1. SDS-PAGE of OMPs (silver stained) of Hib strain Eagan from bacteria grown in vitro (lane 1) or in vivo (lane 2). Loading was $10 \mu \mathrm{g}$ protein per lane. Molecular mass markers $(\mathrm{kDa})$ are on the right and the nomenclature for the major outer-membrane proteins on the left.

$\mathrm{Cl}, \mathrm{D} 1$ and E1). In particular, a band of $81 \mathrm{kDa}$ was recognized by pooled rat and all three human convalescent sera, although the serum from patient $\mathrm{C}$ also identified a faint band of this molecular mass in in vitro isolated membranes. A $48 \mathrm{kDa}$ band was found in patient $D$, and a $43 \mathrm{kDa}$ protein in patient $C$ and pooled rat sera. There were strong responses to OMPs $d, d^{*}$ and $e$ in both membrane preparations by all sera. Serum from uninfected age-matched rats had a band of reactivity of the same molecular mass as OMP d (37 kDa) in both in vitro and in vivo membrane preparations (data not shown). No bands of reactivity were found with detergent-extracted inflammatory cell preparations obtained after the first centrifugation following direct harvesting (see Methods) with rabbit, rat or human sera (data not shown).

\section{Discussion}

The aim of this study was to detect immunogenic proteins 'novel' to infection. The approach taken was one similar to that used successfully in studies on Vibrio cholerae (Jonson et al., 1989). A major problem with $\mathrm{Hib}$ is obtaining sufficient in vivo material. Practical and ethical considerations relating to humans, and the prohibitive numbers required for animal experiments preclude obtaining sufficient nasopharyngeal, blood or CSF material. One possible limitation of this study is that the in vivo material, isolated from i.p.-infected rats, may not reflect the membrane composition of bacteria from other anatomical sites in rat or man. However, given the above constraints, i.p.-grown bacteria were chosen as the source of in vivo derived organisms.

The results show that there were differences in OMP profile between in-vivo- and in-vitro-grown organisms. The major OMPs a and $\mathrm{d}$ may be down-regulated in vivo. van Alphen et al. (1990) also found that the amount of OMP $\mathrm{d}$ was reduced in similar circumstances. The role in virulence, if any, of the 51 and $92 \mathrm{kDa}$ proteins which are relatively over-expressed in vivo remans to be determined.

Immunogenic proteins present in infection were identified using serum raised against in-vivo-grown organisms and absorbed with in-vitro-grown whole cell lysates. The most striking difference between in-vivo- and in-vitro-grown organisms in the immunoblots was the recognition of an $81 \mathrm{kDa}$ protein by rabbit, rat and human sera in in-vivo-grown bacteria. Larger numbers of human sera need to be screened to determine the prevalence of immunological response to this protein. We cannot categorically say whether the proteins of the same molecular mass recognized by the different sera are the same. It is possible that co-migrating proteins of the same molecular mass were present, and were recognized by different sera. With silver staining there appeared to be $81 \mathrm{kDa}$ proteins present in membranes of both in-vitro- and in-vivo-grown organisms. One possibility is 


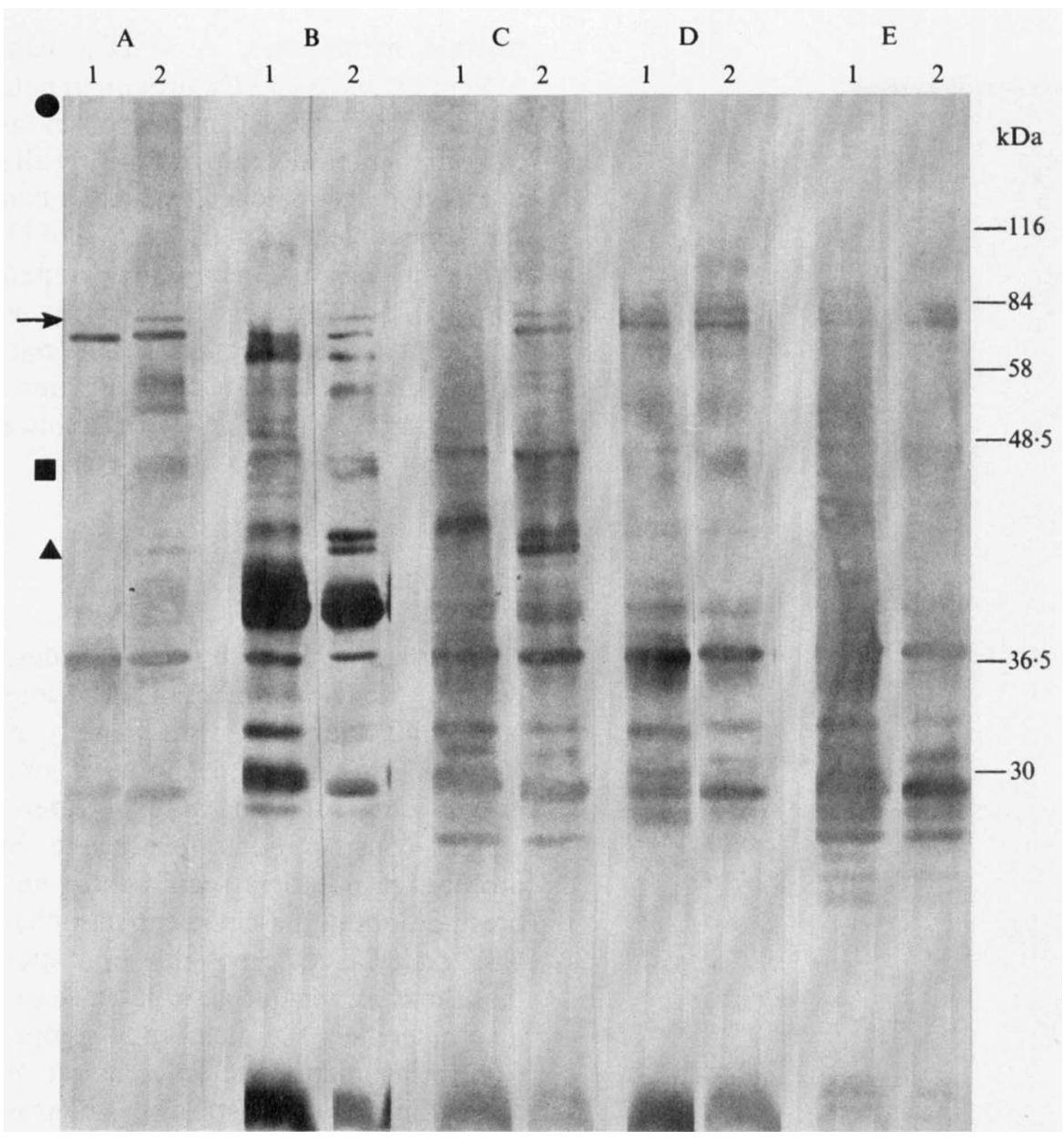

Fig. 2. Identification of immunogenic proteins in infection. Outer membranes of bacteria grown in vitro (lanes 1 ) and in vivo (lanes 2 ) $(10 \mu \mathrm{g}$ protein per lane) were immunoblotted to nitrocellulose and probed with different sera. Lane (A), rabbit anti-in-vivo absorbed with whole-cell lysates of in-vitro-grown organisms; lane (B), pooled convalescent rat sera. Lanes (C, D, E), human convalescent sera from patients C, D and E, respectively (see Methods). Molecular mass markers (kDa) are on the right. On the left, bands of reactivity present in infection (lane A 2) with comparable molecular mass bands in rat or human convalescent sera (see text for details). Their molecular masses were $43 \mathrm{kDa}(\Delta), 48 \mathrm{kDa}(\square), 81 \mathrm{kDa}(\rightarrow)$ and $>200 \mathrm{kDa}(\bullet)$.

that, assuming both proteins are the same in each preparation, the reactivity in immunoblots with in vivo membranes is due to a conformational change. Crossreacting antibodies to other microbial species cannot be ruled out in the case of rabbit and human sera, although this is unlikely with the rat serum given the antibody response of the control rat serum. Rabbit serum raised against $\mathrm{Hib}$ was cross reactive with OMPs from $H$. parainfluenzae and Bordetella pertussis, although this was marginal with B. pertussis (Erwin et al., 1988). Whether the proteins found in infection are surface-exposed is unknown.

Van Alphen et al. (1990) compared the OMP profiles of rat (i.p.)-, serum-, broth-, chocolate-agar- and Ferestricted-grown $\mathrm{Hib}$ organisms. It was suggested that additional proteins in the $50-75 \mathrm{kDa}$ range present in serum-, rat- and chocolate-agar-grown organisms were Fe-regulated. In the present study, an identical immunoblot profile was found for broth- and Fe-restrictedgrown cells, thus the immunogenic proteins present in infection did not appear to have counterparts expressed under Fe-restricted conditions. The response of $\mathrm{Hib}$ to Fe-restriction may, in part, be strain-specific. With Eagan, the same OMP profile in silver-stained gels was found in Fe-restricted and in Fe-replete conditions (Morton \& Williams, 1990), although other strains have been shown to have inducible OMPs visible with Coomassie blue (Williams \& Brown, 1986) or silver staining (Pidcock et al., 1988) under conditions of Ferestriction. Variations in strain, media source, growth phase and the $\mathrm{Fe}$ chelator used make comparison between studies difficult. 
Ideally, an in vitro growth condition which results in bacteria having a composition or properties similar to that in vivo is optimal. In practice, this is difficult to achieve. Growth in broth plus serum filtrate, for example, produces serum-resistant cells resembling those found in vivo (Shaw et al. 1974). The rabbit and rat sera generated in this study can be used to determine if these, or other, in vitro conditions result in expression of immunogenic proteins present in infection. Once found, these will facilitate studies aimed at elucidating whether such proteins are important in the disease process. Studies are in progress to isolate enough of the $81 \mathrm{kDa}$ protein for $\mathrm{N}$-terminal sequencing. Subsequent genetic and virulence studies may elucidate the role, if any, of this protein in pathogenesis. Whether any of the other immunogenic proteins found in this study to be present in infection are important in the disease process, remains to be determined.

This study was supported by an MRC Programme Grant (A.E. W.) and a Wellcome Trust Grant (P.R.L.) awarded to E.R.M.

\section{References}

Allan, I., Loeb, M. R. \& Moxon, E. R. (1987). Limited genetic diversity of Haemophilus influenzae (type b). Microbial Pathogenesis 2 , 139-145.

Anderson, P., Johnston, R. B. \& Smith, D. H. (1972). Human serum activities against Haemophilus influenzae, type b. Journal of Clinical Investigation 51, 31-38.

van Alphen, L., Riemens, T., Poolman, J. \& Zanen, H. C. (1983). Characteristics of major outer membrane proteins of Haemophilus influenzae. Journal of Bacteriology 155, 878-885.

van Alphen, L., Geelen-Van Den Broek, L. \& van Ham, M. (1990). In vivo and in vitro expression of outer membrane components of Haemophilus influenzae. Microbial Pathogenesis 8, 279-288.

Blake, M. S., Johnston, K. H., Russell-Jones, G. J. \& Gotschlich, E. C. (1984). A rapid, sensitive method for detection of alkaline phosphatase-conjugated anti-antibody on Western blots. Analytical Biochemistry 136, 175-179.

BRADFORD, M. M. (1976). A rapid and sensitive method for the quantification of microgram quantities of protein using the principle of dye binding. Analytical Biochemistry 72, 248-254.

Brown, M. R. W. \& Williams, P. (1985). The influence of environment on envelope properties affecting survival of bacteria in infections. Annual Review of Microbiology 39, 527-556.

Erwin, A. L., Kenny, G. E., Smith, A. L. \& Stull, T. L. (1988). Human antibody response to outer membrane proteins and fimbriae of Haemophilus influenzae type b. Canadian Journal of Microbiology 34, 723-729.

Gulig, P. A., McCracken, G. H., JR., Frisch, C. F., Johnston, K. H. \& HANSEN, E. J. (1982). Antibody response of infants to cell surfaceexposed outer membrane proteins of Haemophilus influenzae type b after systemic disease. Infection and Immunity 37, 82-88.

HaNSEN, E. J., FRISCH, C. F., MCDADE, R. L., JR \& JohNSTON, K. H. (1981). Identification of immunogenic outer membrane proteins of Haemophilus influenzae type $b$ in the infant rat model system. Infection and Immunity 32, 1084-1092.
Jacobs, A. A. C. \& de GraAF, F. K. (1985). Production of K88, K99, and $\mathrm{F} 41$ fibrillae in relation to growth phase, and a rapid procedure for adhesin purification. FEMS Microbiology Letters 26, 15-19.

Jonson, G., Svennerholm, A.-M. \& Holmgren, J. (1989). Vibrio cholerae expresses cell surface antigens during intestinal infection which are not expressed during in vitro culture. Infection and Immunity 57, 1809-1815.

KROLL, J. S. \& MoXoN, E. R. (1989). Genetic and phenotypic variation in the capsulation and virulence of culture collection strains of Haemophilus influenzae type b. Microbial Pathogenesis 7, 449-457.

LOEB, M. R. \& SMITH, D. H. (1982). Human antibody response to individual outer membrane proteins of Haemophilus influenzae type b. Infection and Immunity 37, 1032-1036.

Miller, V. L., Taylor, R. K. \& Mekalanos, J. J. (1987). Cholera toxin transcriptional regulator tox $R$ is a transmembrane DNA binding protein. Cell 48, 271-279.

Morton, D. J. \& Williams, P. (1990). Siderophore-independent acquisition of transferrin-bound iron by Haemophilus influenzae type b. Journal of General Microbiology 136, 927-934.

Moulder, J. W. (1985). Comparative biology of intracellular parasitism. Microbiological Reviews 49, 298-337.

Moxon, E. R. (1990). Haemophilus influenzae. In Principles and Practice of Infectious Diseases, pp. 1722-1730. Edited by G. L. Mandell, R. G. Douglas, Jr and J. E. Bennett. Churchill Livingstone: New York.

Murphy, J. R., Pappenheimer, A. M., JR \& Tayart De Borms, S. (1974). Synthesis of diptheria tox-gene products in Escherichia coli extracts. Proceedings of the National Academy of Sciences of the United States of America 71, 11-15.

Pidcock, K. A., Wooten, J. A., Daley, B. A. \& Stull, D. A. (1988). Iron acquisition by Haemophilus influenzae. Infection and Immunity 56, 721-725.

ROGERS, H. J. (1973). Iron-binding catechols and virulence in Escherichia coli. Infection and Immunity 7, 445-456.

Rubin, L. G., Zwahlen, A. \& Moxon, E. R. (1985). Role of intravascular replication in pathogenesis of experimental bacteremia due to Haemophilus influenzae type b. Journal of Infectious Diseases 152, 307-314.

Schnaitman, C. A. (1971). Effect of ethylenediaminetetraacetic acid, Triton X-100, and lysozyme on the morphology and chemical composition of the isolated cell walls of Escherichia coli. Journal of Bacteriology 108, 553-563.

Shaw, S., Smith, A. L., Anderson, P. \& Smith, D. H. (1974). The paradox of Haemophilus influenzae type b bacteremia in the presence of serum bactercidal activity. Journal of Clinical Investigation 58, 1019-1029.

STOSCHECK, C. M. (1990). Increased uniformity in the response of the Coomassie blue $\mathrm{G}$ protein assay to different proteins. Analytical Biochemistry 184, 111-116.

Taylor, R. K., Miller, V. L., Furlong, D. B. \& Mekalanos, J. J. (1987). Use of phoA gene fusions to identify a pilus colonisation factor coordinately regulated with cholera toxin. Proceedings of the National Academy of Sciences of the United States of America 84, 2833-2837.

Towbin, H., Staehelin, T. \& GoRdon, J. (1979). Electrophoretic transfer of proteins from polyacrylamide gels to nitrocellulose sheets: procedure and some applications. Proceedings of the National Academy of Sciences of the United States of America 76, 43504354.

Williams, A. E., Maskell, D. J. \& Moxon, E. R. (1991). Relationship between intracellular survival in macrophages and virulence of Haemophilus influenzae type b. Journal of Infectious Diseases 163, 1366-1369.

Williams, P. \& Brown, M. R. W. (1986). The influence of iron restriction on growth and the expression of outer membrane proteins by Haemophilus influenzae and Haemophilus parainfluenzae. FEMS Microbiology Letters 33, 153-157. 